\title{
PALEOENVIRONMENTAL ANALYSIS OF (PETRO)CALCIC SOIL HORIZONS IN THE MOJAVE DESERT
}

COLIN R. ROBINS, Claremont McKenna, Pitzer, and Scripps Colleges (The Claremont Colleges Consortium)

\section{INTRODUCTION}

Compared to humid environments, in which extensive chemical leaching and organic matter additions dominate soil formation pathways, arid soils are shaped much more by the accumulation of ions via evaporating, alkaline solutions and dust (Gile et al., 1981). Over time, this accumulation can completely cement desert soil horizons with pedogenic carbonates, sulfates, nitrates, halides, or even unique phyllosilicates (Dixon and Weed, 1989; Brady \& Weil, 2008; Graham et al., 2008; Brock-Hon et al., 2012; Robins et al., 2012), and entire landforms can become armored by their soil profiles against erosion or further infiltration. Importantly, small changes in temperature or precipitation can impart larger magnitude responses in arid soil chemistry and mineralogy, plant growth and plant distributions, geomorphic stability, dust flux, and more (Chadwick and Chorover, 2001). Thus, in the face of warming global climate and increasing desert populations (Theobald et al., 2013), it is imperative to understand (1) how arid soils record past climate or geomorphic change, and (2) how arid soilgeomorphic surfaces are likely to respond to future climate change.

Calcite is among the most common pedogenic minerals to precipitate in arid climates, and soil classification systems worldwide note its importance (e.g., Soil Survey Staff, 2014; IUSS Working Group WRB 2006; and others). Given a stable climate and geomorphic surface, calcic soil horizons can evolve progressively from simple, "Stage I" horizons with thin dustings of carbonate through the soil matrix or along root traces, to "Stage III" horizons completely plugged by calcite that begin to inhibit infiltration, and finally, over 106 a timescales, into endmember
"Stage VI" petrocalcic horizons brecciated or partially dissolved and then recemented by pluvial-interpluvial climate fluctuations (Machette, 1985; Schoeneberger et al., 2012). This six-stage model ascribes relative ages to soil morphology in a way that Soil Taxonomy's three-fold Bk (calcic), Bkk (calcic to petrocalcic), and Bkkm (petrocalcic) horizon classification (Soil Survey Staff, 2014) does only with less precision. However, rates of calcic and petrocalcic horizon genesis vary widely from site to site and between regions depending on parent material, climate, and dust flux, and the six-stage model is not perfect.

For instance, the model inadequately illustrates the mineralogical evolution of (petro)calcic horizons (e.g., Robins et al., 2012), each of which can include unique assemblages including palygorskite, sepiolite, and even barite (Brock-Hon et al., 2012) or fluorite (Bouza et al., 2007). Nor does the model address the timing and evolution of all micromorphological features found in calcic horizons, for instance excluding pedogenic ooids (Robins et al., 2015). Finally, the model is horizon-centric, meaning that individually tailored profile-scale models (e.g., Alonzo-Zarza et al., 1998; Brock and Buck, 2009; Alonzo-Zarza and Silva, 2002) must be developed on a site-by-site basis for polygenetic profiles, and for any soil with more than one calcic or petrocalcic horizon.

Ultimately, one of the most important applications of pedogenic carbonate analysis is the interpretation of paleoenvironmental data from stable isotope geochemistry (Zamanian et al., 2016). Isotopic analysis of pedogenic $\mathrm{CaCO} 3(\delta 13 \mathrm{C}$ and $\delta 18 \mathrm{O})$, phyllosilicates $(\delta 180)$, and barite $(\delta 34 \mathrm{~S}$ and $\delta 180)$ from different soil developmental stages can yield useful insights into paleovegetation (e.g., Deutz et 
al., 2001), paleotemperature (Quade et al., 2013), microbial activity (e.g., Jennings and Driese, 2014), and more. However, accurate interpretations rely on closed system assumptions that may be violated by partial or complete dissolution/reprecipitation of pedogenic calcite over time. Micromorphological context is also critical for accurate isotope interpretation because different micromorphological features form at different times within (petro) calcic horizons, and it is possible to mix data from calcite of different ages. Other pedogenic minerals in calcic horizons have not yet been well studied isotopically, and it is unknown whether the pedogenic phyllosilicates which form concurrently with calcite (Robins et al., 2012), for instance, better resist dissolution and later crystal growth additions than calcite.

The goal of Team Nevada (Figure 1), a Keck Geology Consortium Advanced Research project, was to advance the understanding of the mineralogic, geochemical, and micromorphological evolution of (petro)calcic horizons, using stage II-VI horizons from an ancient soil geomorphic surface in the Mojave Desert as a case study for processes relevant worldwide and in the stratigraphic record. These projects refine existing models of carbonate horizon development, and provide new isotope data for the Mormon Mesa surface in southeastern Nevada.

\section{STUDY AREA}

Mormon Mesa hosts perhaps the oldest, extant petrocalcic soil profile in North America (Figure 2). Its profile is a sequence of petrocalcic (Bkkm) horizons capping sediments of the Miocene-Pliocene Muddy Creek Formation (MCF) (Gardner, 1972; Brock and Buck, 2009; Soil Survey Staff, 2019). MCF deposits are fluvial and eolian sediments deposited in a closed basin prior to incision of the Virgin River upon interception by the lower Colorado River (Kowallis and Everett, 1986; Williams et al., 1997). Incision of the Virgin River to the east, and of Muddy Creek to the west produced $\sim 200 \mathrm{~m}$ relief between the mesa and the floodplains (Fig. 2), with other fragments of the mesa surface preserved nearby as smaller mesas or buttes (e.g., Flat Top Mesa). Combined with an overall arid climate history, incision is hypothesized to have ended any interaction of the Mormon Mesa soil with groundwater, however, there are no published stable isotope data to confirm this long-standing assumption. Onset of pedogenesis at Mormon Mesa is considered synchronous with incision of the lower Colorado River system 5.6 - 4.2 Ma (Faulds et al., 2002; House et al., 2005), and a 5-4 Ma surface age is further supported by stratigraphic and morphostratigraphic correlation with isotopically dated tuffs and basalts (Schmidt et al., 1996; Williams et al., 1997; Faulds et al., 2002).

The Mormon Mesa soil profile (Figure 3) has been previously described and variably interpreted (Gardner, 1972; Bachman and Machette, 1977; Brock and Buck, 2009; Soil Survey Staff, 2019). Its currently accepted geomorphic history was interpreted by Brock and Buck (2009), and models for its mineral evolution (Robins et al., 2012) and the genesis of its pedogenic ooids (Robins et al., 2015) have been recently published also. The uppermost MCF strata exhibit carbonate nodules (a stage II paleosol), and are capped by a popcorn-textured, stage III "transitional" horizon forming the base of the Mormon Mesa profile (Brock and Buck, 2009). Subsequent sedimentation or erosion, followed by periods of geomorphic stability and pedogenesis, produced three to four more horizons (laminar layer, massive horizon, brecciated horizon, and a rubble layer interspersed with eolian sands) above the transitional (Brock and Buck, 2009). Locally, fluvial incision and backfilling has produced younger, nested profiles with petrocalcic horizons that cross-cut the older soil (Conley et al., 2018). Further, pedogenic laminae, pisoliths (e.g., irregular, $>2 \mathrm{~mm}$ concretions indicative of rotation), dissolution voids and other features reflect complex episodes of calcite precipitation, horizon brecciation, and re-cementation (Brock and Buck, 2009; Robins et al., 2015).

Despite the research to date, Mormon Mesa's polygenetic nature and micro-morphological and mineralogical complexity beg further study. None of the published models have been validated with stable isotope data. Detailed elemental geochemical comparisons have not been made for minerals between horizons nor between micromorphological features (e.g., laminae, pisoliths, matrix, dissolution voids). Importantly, models developed at Mormon Mesa can 


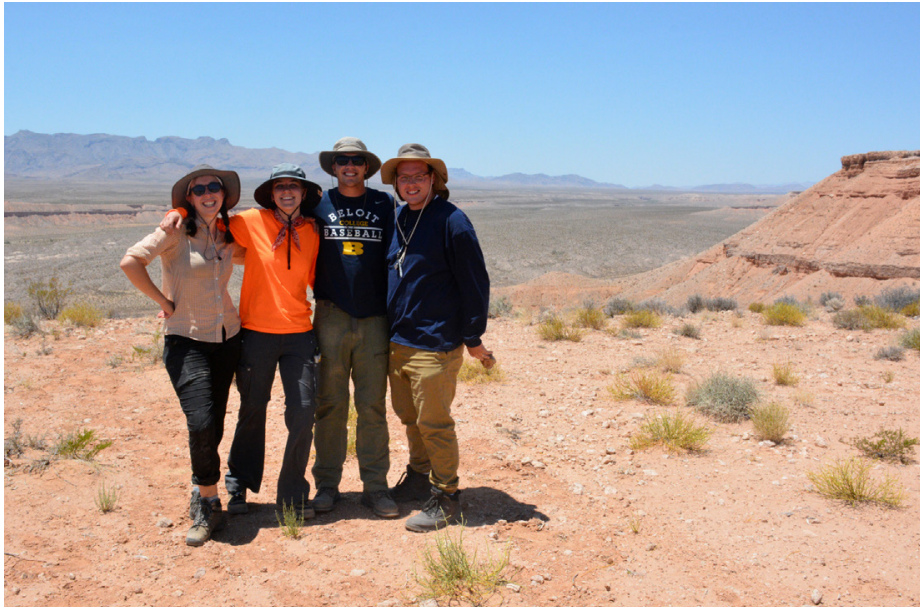

Figure 1: Team Nevada concludes field work at Flat Top Mesa on June 26, 2018. From left to right: I. Futterman, P. Vorster, E. Conley, and K. Crandall.

be cautiously applied for insights into other (petro) calcic horizons and paleosols worldwide.

\section{METHODOLOGY}

This study involved four, closely-linked projects investigating the mineralogical, geochemical, and micromorphological evolution of the Mormon Mesa soil and geomorphic surface. Field work measuring section, describing soil profiles, and sampling was conducted in June, 2018. Three sites were chosen for detailed analysis: (1) the previously studied Mormon Mesa Riverside site (e.g., Brock and Buck, 2009; Brock-Hon et al., 2012; Robins et al., 2012; Robins et al., 2014; Robins et al., 2015), and two previously undescribed profiles in exposures at (2) Flat Top Mesa East, and (3) Flat Top Mesa West (Figure 2). Additionally, surface samples (top $10 \mathrm{~cm}$ ) were collected for geochemical analysis from two Mormon Mesa transects, one Flat Top Mesa transect, and from representative geomorphic features on both mesas.

Intact, oriented and sometimes unoriented samples were collected using either a rock hammer and chisel, or a concrete cutting saw. Samples were labeled and stored in plastic boxes for transport to the laboratory. For geochemical study via X-ray fluorescence (XRF) and inductively coupled plasma (ICP) spectrometry, additional, surface samples were collected using a trowel and stored in plastic zip bags.

Initial sample processing was conducted in Claremont, CA. Billets were cut on a diamond-bladed tile saw and shipped to Spectrum Petrographic Inc. (Vancouver, WA), for thin section preparation. Additional billets were polished for reflected light microscopy and/ or scanning electron microscopy (SEM) with energy dispersive spectrometry (EDS) analysis. Samples for stable isotope analysis were trimmed to target specific micromorphological features including laminar caps, matrix, and pisoliths; these samples were divided into aliquots for carbonate isotope analysis and phyllosilicate analysis. Samples were shipped to Beloit College (Conley), Pitzer College (Crandall), Mount Holyoke College (Vorster), and Vassar College (Futterman) for individual projects.

Team Nevada presented preliminary findings at the 2018 Geological Society of America Meetings in Indianapolis (Conley et al., 2018), and continued their work through March, 2019.

\section{STUDENT PROJECTS}

\section{Pedogenic ooids}

Ethan Conley (Beloit College, WI) investigated the formation of pedogenic ooids - small, concentrically banded concretions - in (petro)calcic horizons with a systematic study of their morphology, and, importantly, presence or absence within individual horizons and features. Soil ooids are similar to sedimentological ooids - both are roughly spherical and composed of concentric authigenic mineral layers. However, pedogenic ooids exhibit a wider range of morphologies (e.g., with or without a single or complex nucleus), and compositions (calcite, clay, and/or oxide coats). Often this diversity of form and composition occurs in one spot, with different types of ooids immediately adjacent to one another in the soil. Further complicating matters, micromorphological terminology has proliferated within soil science, such that ooid-like features have variably been called coated grains, concretions, glaebules, globules, granules, microaggregates, nodules, ooids, pellets, peloids, pisoids, pisolites, and other terms that have different meanings between or even within disciplines (see Bachman and Machette, 1977; Chafetz and Butler, 1980; Durand et al., 2010; Kendall et al., 2014; and others). Robins et al. (2015) suggested that chemical precipitation and the wetting of pedogenic 
phyllosilicates within the ooid structure might explain much of the morphological variation observed in soils, but this model requires further testing.

Using optical light microscopy and SEM analysis, Ethan described, photographed, and classified ooids from 18 samples, comparing their morphology and context to published descriptions of ooids and comparable features in the literature. Ethan's analysis presents a new classification model positing three distinct genesis pathways for ooid occurrence in soils, including (1) simple, chemically precipitated grain coats, (2) biological, calcified excrements or castings, and (3) erosional features in horizon fracture and joint fillings.

\section{Pedogenic laminae}

Kurt Crandall (Pitzer College, CA) investigated correlations among the micromorphology, color, mineralogy, and geochemistry of pedogenic carbonate

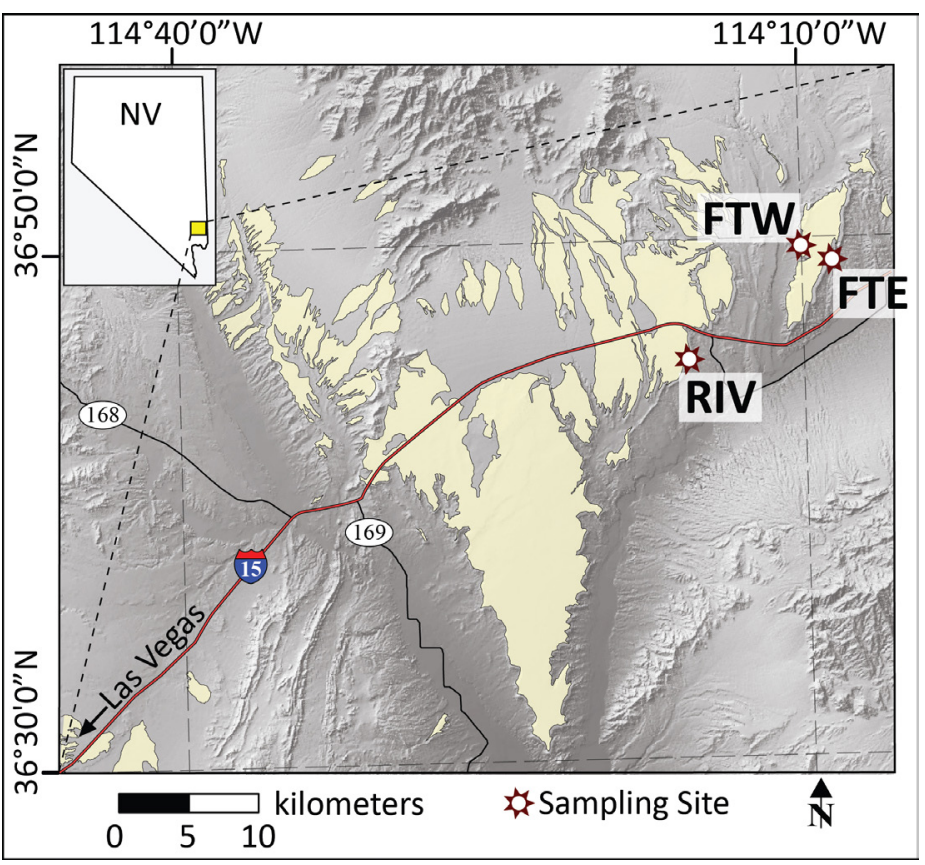

Figure 2: Location of the Mormon Mesa soil-geomorphic surface in southern Nevada; studied profiles include RIV = Riverside, FTW = Flat Top Mesa West and FTE = Flat Top Mesa East. Yellow polygons/shading represent approximate extent of the Mormon Mesa soil series (modified from Soil Survey Staff, 2006). Digital elevation base data modified from USGS (2005). laminae in petrocalcic horizons, reconsidering existing hypotheses for laminar genesis. Importantly, in the six-stage model of progressive horizon calcification, $>1 \mathrm{~cm}$ thick sequences of laminae define transition from a Stage III calcic to a Stage IV petrocalcic horizon, when infiltration is restricted and percolating soil waters are diverted laterally across the top of the plugged horizon. However, the six-stage model does not address laminae formed by piping or other processes, and field observations suggest alternate pathways bear consideration.

Combining field observations, reflected and transmitted light microscopy, SEM-EDS, laser ablation ICP, and 3D surface scanning, Kurt defined six distinct laminar classes. Each differs in crystal size, mineralogy, and/or elemental abundances (especially $\mathrm{Fe}$ ). These new data in context with field observations will help revise existing models for laminar genesis, and may help direct more targeted sampling protocols for stable isotope analysis.

\section{Pedogenic barite}

India Futterman (Vassar College, NY) conducted a landform-scale geochemical analysis to test competing hypotheses about $\mathrm{Ba}$ sources behind barite authigenesis in Mormon Mesa's petrocalcic horizons. Pedogenic barite confirmed in the Stage VI petrocalcic horizons at Mormon Mesa only recently (BrockHon et al., 2012), but may occur in other petrocalcic horizons around the world. This is significant because barite is a relatively insoluble mineral not previously thought to form in non-saline, arid-climate soils. Two competing hypotheses for $\mathrm{Ba}$ ion sources include (1) Ba weathered from parent material, especially volcanic ash, and (2) Ba input via eolian dust, especially from playas or from Ba-Mn oxides (hollandite) in desert varnish.

Using XRF and ICP analysis alongside geomorphic mapping, India measured the concentration of $\mathrm{Ba}$ and other ions in over 80 samples from three transects and numerous landform types across the Mormon and Flat Top Mesa surfaces. Her data show intriguing trends between $\mathrm{Ba}$ concentrations and surface geomorphology, suggesting that an eolian source may predominate over parent materials in barite authigenesis. 


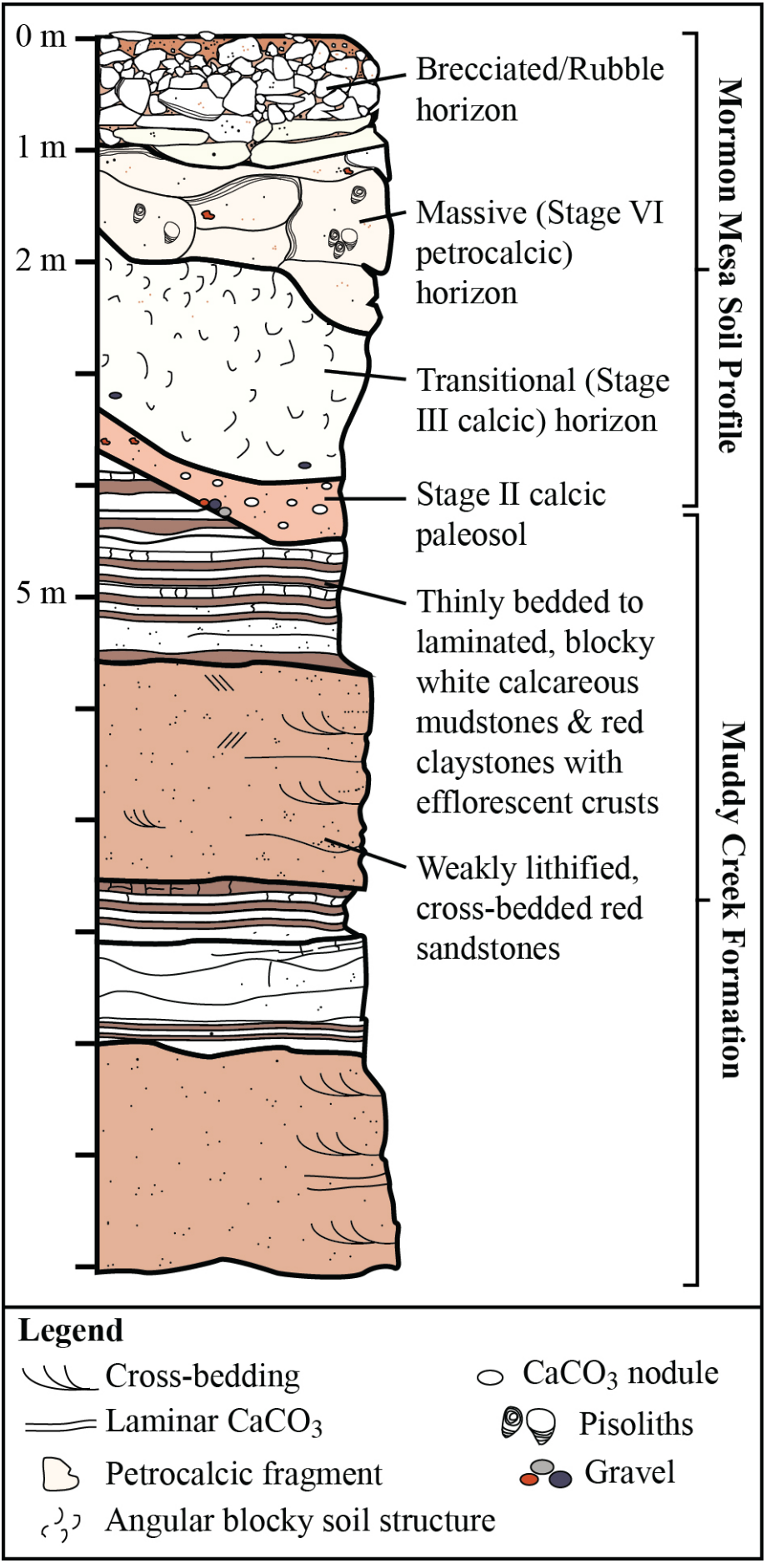

Figure 3: Generalized soil profile and stratigraphic section as measured at Riverside, using informal horizon nomenclature (e.g., Rubble, Brecciated, Massive, and Transitional horizons) of Brock \& Buck (2009).

\section{Stable isotope variation}

Penelope Vorster (Mount Holyoke College, MA) used stable isotope geochemistry to seek differences in closed-system behavior between distinct micromorphological components of Mormon Mesa's (petro)calcic horizons, especially nodules, pisoliths, laminae, and matrix. Importantly, Stage VI petrocalcic horizons develop like a conglomerate, containing brecciated fragments of precursor horizons that were variably eroded, redeposited, and recemented into a new horizon during Pleistocene climate oscillations. In targeting petrocalcic horizons for isotopic analysis and paleoenvironmental reconstruction, it is sometimes unclear whether the carbonate has resisted dissolution sufficiently to record the initial pedogenic environment, or whether it instead records younger calcite replacement or overprinting.

Penelope's analysis reveals widely variable $(<$ $0.5 \mathrm{~g}$ to $>6.0 \mathrm{~g}$ per $\sim 100 \mathrm{~g}$ of petrocalcic sample) phyllosilicate abundance across the massive horizon of Mormon Mesa, its laminae, pisoliths, and undifferentiated matrix, and her stable isotope analysis of the pedogenic carbonate shows intriguing trends between horizons with regard to their $\delta 13 \mathrm{C}$ signature (by contrast, $\delta 180$ spanned a similar range across all horizons). These results provide important new data with which to test and refine models (Brock and Buck, 2009) for Mormon Mesa's evolution from the Pliocene to the Holocene.

\section{SUMMARY AND CONCLUSIONS}

The Mormon Mesa soil geomorphic surface continually proves more complex than previously imagined. These studies offer new models for the genesis of pedogenic carbonate laminae and ooids, and offer new insights into the origins of ions driving pedogenic barite crystallization. We anticipate additional phyllosilicate mineral and isotope data soon, as well as additional analyses of surface geochemistry that will shed further light on the evolution of polygenetic soil profiles with multiple calcic and petrocalcic horizons. Student research will help refine existing models for the development of petrocalcic horizons in modern soils as well as in paleosols.

\section{ACKNOWLEDGEMENTS}

This material is based upon work supported by the Keck Geology Consortium and the National Science Foundation under Grant No. 1659322, with 
additional support from the Pomona College Geology Department, and the W.M. Keck Science Department of Claremont McKenna, Pitzer, and Scripps Colleges. I am indebted to J. Harris, K. McCarty, J.S. Lackey, M. Alfaro, B. Jaeger, K. Wirth, C. Davidson, M. Miller, and F. Bedoya for their assistance with the planning, administration, logistical operations, and analytical activities of this project. I thank S. Dunn, R. Gaines, E. Grosfils, K. Menking, and J. Rougvie for their generous on-campus mentorship and support of Team Nevada's research.

\section{REFERENCES}

Alonso-Zarza, A., Silva, P.G., Goy, J.L., and Zazo, C., 1998. Fan-surface dynamics and biogenic calcrete development: Interactions during ultimate phases of fan evolution in the semiarid SE Spain (Murcia). Geomorphology 24: 147-167.

Alonso-Zarza, A.M. and Silva, P.G., 2002. Quaternary laminar calcretes with bee nests: evidences of small-scale climatic fluctuations, Eastern Canary Islands. Palaeogeography, Palaeoclimatology, Palaeoecology 178: 119-135.

Bachman, G.O., and Machette, M.N., 1977. Calcic soils and calcretes in the southwestern United States. U.S. Geological Survey Open File Report 77-794. U.S. Government Printing Office, Washington, DC.

Bouza, P.J., Simón, M., Aguilar, J., del Valle, H., and Rostagno, M., 2007. Fibrous-clay mineral formation and soil evolution in Aridisols of northeastern Patagonia, Argentina. Geoderma 139 (1-2): 38-50.

Brady, N.C. and Weil, R.R., 2008. The nature and properties of soils, fourteenth edition (revised). Pearson Prentice Hall, Upper Saddle River.

Brock, A.L. and Buck, B.J., 2009. Polygenetic development of the Mormon Mesa, NV petrocalcic horizons: Geomorphic and paleoenvironmental interpretations. Catena 77 :
$65-75$

Brock-Hon, A.L., Robins, C.R., and Buck, B.J., 2012. Micromorphological investigation of pedogenic barite in Mormon Mesa petrocalcic horizons, Nevada USA: Implication for genesis. Geoderma 179-180: 1-8.

Chadwick, O.A. and Chorover, J., 2001. The chemistry of pedogenic thresholds. Geoderma 100: 321-353.

Chafetz, H.S. and Butler, J.C., 1980. Petrology of recent caliche pisolites, spherulites, and speleothem deposits from central Texas. Sedimentology 27: 497-518.

Conley, E., Crandall, K., Futterman, I., Vorster, P., and Robins, C.R., 2018. Preliminary new insights into the evolution of an extant 4-5 Ma soilgeomorphic surface and its unique petrocalcic horizons, southern Nevada, USA. Geological Society of America Abstracts with Programs 50 (6): 193-2.

Deutz, P., Montañez, I.P., Monger, H.C. and Morrison, J., 2001. Morphology and isotope heterogeneity of Late Quaternary pedogenic carbonates: Implications for paleosol carbonates as paleoenvironmental proxies. Palaeogeography, Palaeoclimatology, Palaeoecology 166 (3-4): 293-317.

Dixon, J.B., and S.B. Weed, eds., 1989. Minerals in soil environments, 2nd edition. SSSA Book Series 1. Soil Science Society of America, Madison, WI.

Durand, N., Monger, H.C., and Canti, M.G., 2010. Calcium carbonate features. In: Stoops, G., Marcelino, V., and Mees, F., Editors. Interpretation of micromorphological features of soils and regolith. Amsterdam: El Sevier: 149194.

Faulds, J.E., L.A. Gonzalez, M.E. Perkins, P.K. House, P.A. Pearthree, S.B. Castor, and Patchett, P.J., 2002. Late Miocene-Early Pliocene transition from lacustrine to fluvial deposition: inception 
of the lower Colorado River in southern Nevada and northwest Arizona. Geological Society of America Abstracts with Programs 34(4): 60.

Gardner, L.R., 1972. Origin of the Mormon Mesa Caliche, Clark County, Nevada. Geological Society of America Bulletin 83: 143-156.

Gile, L.H., Hawley, J.W. and Grossman, R.B., 1981. Soils and geomorphology in the Basin and Range area of Southern New Mexico - Guidebook to the Desert Project. New Mexico Bureau of Mines \& Mineral Resources, Memoir 39. University of New Mexico, Socorro, 222 pp.

Graham, R.C., Hirmas, D.R., Wood, Y.A. and Amrhein, C., 2008. Large near-surface nitrate pools in soils capped by desert pavement in the Mojave Desert, California. Geology 36(3): 259262.

House, P.K., Pearthree, P.A., Howard, K.A., Bel, J.W., Perkins, M.E., Brock, A.L., 2005. Birth of the lower Colorado River - Stratigraphic and geomorphic evidence for its inception near the conjunction of Nevada, Arizona, and California, in: Pederson, J., Dehler, C.M., eds., Interior Western United States: Boulder Colorado, Geological Society of America Field Guide 6. Geological Society of America, Boulder.

IUSS (International Union of Soil Scientists) Working Group WRB, 2006. World reference base for soil resources 2006. World Soil Resources Reports No. 103. Food and Agricultural Organization of the United Nations, Rome.

Jennings, D.S. and Driese, S.G., 2014. Understanding barite and gypsum precipitation in upland acid-sulfate soils: An example from a Lufkin Series toposequence, south-central Texas, USA. Sedimentary Geology 299: 106-118.

Kendall, C., Alnaji, N., McCarney-Castle. K., Marshall, B., Editors, 2014. Stratigraphy of Rocks and Sediments. SEPM (Society for Sedimentary Geology) Strata Website: http:// www.sepmstrata.org/ [Accessed 8/22/2014].
Kowallis, B.J., and Everett, B.H. 1986. Sedimentary environments of the Muddy Creek Formation near Mesquite, Nevada. Sed. Assoc. Pub. 15:6975.

Machette, M.N., 1985. Calcic soils of the southwestern United States. In: D.L. Weide (Editor), Soils and Quaternary Geology of the southwestern United States: 1-21.

Quade, J., Eiler, J., Daëron, M. and Achyuthan, H., 2013. The clumped isotope geothermometer in soil and paleosol carbonate. Geochimica et Cosmochimica Acta 105(Supplement C): 92-107.

Robins, C.R., Brock-Hon, A.L. and Buck, B.J., 2012. Conceptual mineral genesis models for calcic pendants and petrocalcic horizons, Nevada. Soil Science Society of America Journal 76(5): 18871903.

Robins, C.R., Buck, B.J., Spell, T.L., Soukup, D.A. and Steinberg, S.M., 2014. Testing the applicability of vacuum-encapsulated 40Ar/39Ar geochronology to pedogenic palygorskite and sepiolite. Quaternary Geochronology 20: 8-22.

Robins, C.R., Deurlington, A., Buck, B.J. and Brock-Hon, A.L., 2015. Micromorphology and formation of pedogenic ooids in calcic soils and petrocalcic horizons. Geoderma, 251-252: 10-23.

Schmidt, D.L., W.R. Page, and Workman, J.B., 1996. Preliminary geologic map of the Moapa West Quadrangle, Clark County, Nevada. U.S. Geological Survey Open-File Report 96-521.

Schoeneberger, P.J., Wysocki, D.A., Benham, E.C., Broderson, W.D., and Soil Survey Staff, 2012. Field book for describing and sampling soils, Version 3.0. Lincoln: Natural Resources Conservation Service, National Soil Survey Center.

Soil Survey Staff. 2006. Official Soil Series Descriptions. USDA-NRCS http://soils.usda.gov/ technical/classification/osd/index.html (accessed 1 April 2006).

Soil Survey Staff, 2014. Keys to Soil Taxonomy, 
Twelfth Edition. Lincoln: United States

Department of Agriculture Natural Resources

Conservation Service.

Soil Survey Staff, 2019. Official Soil Series

Descriptions. USDA-NRCS http://soils.usda.gov/ technical/classification/ osd/index.html (accessed 27 March 2019).

Theobald, D.M., Travis, W.R., Drummond, M.A., and Gordon, E.S., 2013. The Changing Southwest. In Garfin, G., Jardine, A., Merideth, R., Black, M., and LeRoy, S., Eds., Assessment of climate change in the Southwest United States: A report prepared for the National Climate Assessment. Washington, DC. Island Press: 37-55.

United States Geological Survey (USGS), 2005. Seamless Data Distribution Digital Elevation Models. U.S. Department of the Interior http:// seamless.usgs.gov/ (accessed 1 Aug. 2005).

Williams, V.S., Bohannon, R.G. and Hoover, D.L., 1997. Geologic map of the Riverside Quadrangle, Clark County, Nevada, Geologic Quadrangle Map GQ-1770.

Zamanian, K., Pustovoytov, K., Kuzyakov, Y., 2016. Pedogenic Carbonates: Forms and formation processes. Earth Science Reviews 157: 1-17. 